International Journal of Instruction e-ISSN: 1308-1470 • www.e-iji.net

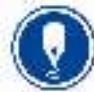

July $2021 \bullet$ Vol.14, No.3

p-ISSN: 1694-609X

pp. 433-450

Article submission code:

20200710104739

Received: $10 / 07 / 2020$

Revision: 25/12/2020
Accepted: 19/01/2021

OnlineFirst: 22/05/2021

\title{
Three Written Corrective Feedback Sources in Improving Indonesian and Japanese Students' Writing Achievement
}

\section{Sonny Elfiyanto}

Ph.D. candidate, Graduate School of Education, Hiroshima University, Japan, elfiyanto@gmail.com

\section{Seiji Fukazawa}

Prof., Hiroshima University, Japan, sfukaza@ hiroshima-u.ac.jp

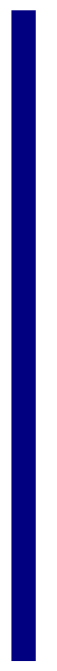

The quality of written corrective feedback can strongly and positively affect students' writing achievement levels. This study aimed to examine whether written corrective feedback could improve students' achievement levels for essay writing and investigated which one from three different feedback sources - teacher, peer, and self-was effective in increasing senior high school students' achievement levels of English writing in two English as a Foreign Language countries, Indonesia and Japan. The study participants included 81 Indonesian and 81 Japanese senior high school students (Grade XI, 16-17 years old), who were divided into three different groups. Three different feedback sources were utilized for each group. Data collection was from a pretest and posttest to identify the relationship between students' writing achievement level and the written corrective feedback sources they had been exposed to in the classroom. The data were analyzed by employing descriptive statistics, ANOVA, and Bonferroni post hoc test. The study results showed that written corrective feedback from peers effectively improved Indonesian senior high school students' writing achievement levels. In contrast, for the Japanese senior high school students, teachers' written corrective feedback represented the most effective source.

Keywords: writing, written corrective feedback, EFL, secondary education, student

\section{INTRODUCTION}

The practice of providing written corrective feedback (WCF) for second or foreign language learners' writing has generated some debate, especially concerning its benefits in improving students' performance. Some scholars have expressed confidence that feedback is an indispensable writing process component that supports students as they develop their English writing skills. This notion regarding WCF received great support from some scholars who suggested that it could be an effective means for error correction and improving students' accuracy relating to writing tasks (Bitchener \& Ferris, 2012; Ferris, 1999; Van Beuningen, De Jong, \& Kuiken, 2012). Further, in the

Citation: Elfiyanto, S., \& Fukazawa, S. (2021). Three written corrective feedback sources in improving Indonesian and Japanese students' writing achievement. International Journal of Instruction, 14(3), 433-450. https://doi.org/10.29333/iji.2021.14325a 
academic area, Chen, Nassaji, and Liu (2016) discovered that WCF had become the most prominent approach for providing feedback in English as a Foreign Language (EFL).

Four language skills must be mastered by senior high school students in Indonesia and Japan. One of the skills is writing, which is considered the most challenging skill for learners to master (Richards \& Renandya, 2002). Moreover, Tillema (2012) said that writing is one of the most important educational success skills, even though it is one of the most challenging skills to be learned. Some studies have been done to investigate the Indonesian students' problem in writing. Ariyanti and Fitriana (2017) found that Indonesian students had problems using grammar, cohesion, coherence, paragraph organization, diction, and spelling in essay writing. Additionally, Toba, Noor, and Sanu (2019) concluded that some participants have problems in writing components, including content, organization, vocabulary, grammar, and mechanics. As a result, Indonesian senior high school students must have skills in understanding the meaning and compiling oral and written texts, using text structures in order and coherently as well as linguistic elements accurately, acceptably, and fluently (Kemendikbud, 2013).

Like Indonesian students, Japanese students have also faced problems in English writing. $64 \%$ of the students were still unable to write using logical structure (Okada, 2018). English is very difficult to acquire for Japanese people. According to Yoshida (2008), the main reasons are that Japan is a homogeneous, monolingual nation, and Japanese have little exposure to English or need to use it in their daily lives. Consequently, the Ministry of Education, Culture, Sports, Science, and Technology (MEXT, 2011) has stated that the main writing goal of English classrooms should be "to accustom and familiarize students with writing in English and to enable them to write about their thoughts using English." Thus, the teacher has the responsibility of facilitating students' learning in English, thereby improving writing skills and confidence that are essential requirements in the MEXT curriculum. Therefore, to achieve those goals, the investigation of whether-and how-WCF is being applied in senior high schools in Indonesia and Japan as a strategy to improve students' writing ability.

Several research studies on the effects of WCF have produced fundamentally different findings. Some scholars have suggested that WCF is not a useful approach for learners. Truscott (1996) found that WCF was very ineffective and, in some cases, even harmful for the provision of CF to students' learning. Moreover, Truscott and Hsu (2008) concluded that improvements made during revisions are not evidence of correction's effectiveness for improving learners' writing ability.

In contrast, Ferris (1999) claimed that CF was a very suitable approach that should be tested in English as a Second Language (ESL) writing classes. She contended that CF could motivate and increase students' confidence if teachers provided feedback about their writing. She argued that, in this way, CF provision could increase students' selfsufficiency in terms of editing their writing products. Bitchener and Storch (2016) supported Ferris' claim that WCF could positively affect writing accuracy. 
Two different viewpoints have posited that WCF is mostly conducted among adult learners and at the university level. Few studies have considered this issue at the senior high school level, particularly in Indonesia and Japan. Thus, it is necessary to conduct substantial research on whether WCF sources can improve Indonesian and Japanese senior high school students' English writing achievement levels and investigate the effectiveness of different sources of WCF.

\section{Review of Literature}

\section{Written Corrective Feedback}

Any information offered by an agent (e.g., teacher, peer, or self) concerning aspects of one's performance is feedback (Hattie \& Timperley, 2007). Therefore, any information regarding the student's achievement levels in relation to learning objectives, which is provided to the teacher and/or the student, is considered as feedback. Feedback should be aimed at aiding advancements in students' learning. Bitchener and Storch (2016) define WCF as a written reply to any linguistic error detected in writing products produced by a student. It tries to correct the detected incorrect usage or pinpoint where the error has occurred and how it can be improved.

The problem of assigning CF to students' written works to enhance their writing has been actively debated since the publication of Truscott's essay (1996), which argued that the application of CF in assessing ESL students' writing was not only useless, but also harmful. In response to Truscott, Ferris (1999) stated that Truscott's claim was incorrect and that CF could be helpful for ESL writers. These different viewpoints sparked an extensive discussion between the two researchers. However, Chandler (2003) argues that CF is a valuable part of ESL writing. He states, "The one implicit point of agreement in Truscott's and Ferris' articles was that the existing data are insufficient to resolve the question of whether error correction can be an effective way to improve the accuracy of L2 writing" (p. 268).

Van Beuningen et al. (2012) found that the application of CF was beneficial for assisting accuracy enhancement among L2 students. This study, which utilized real classrooms, included four sessions: pretest-treatment-posttest-delayed-posttest. Then, the researchers analyzed the first assignments (pretest) and examined errors that appeared in the revised texts (posttest) along with the products that did not receive any feedback. Generally, WCF is beneficial for ESL and EFL writers in improving their written accuracy; however, few studies have been conducted at the secondary level.

Nevertheless, the question of who should provide WCF for students' writing to help them become independent writers and achieve writing skills accuracy remains unanswered. Hendrickson (1978) raised some issues regarding WCF, including "should we correct," "when?," "which errors?," "how?," and "who?" Therefore, this study focused on the question of "who" will provide WCF. It was determined that the providing sources could be a teacher, a peer, or oneself (the writer). 


\section{Teacher Written Corrective Feedback}

Bitchener and Ferris (2012) stated that teacher WCF effectively helps EFL writers; for example, teacher WCF provides marginal comments, clarification requests, and comments regarding grammatical problems. Students hold certain expectations regarding their teachers' feedback on their writings and value such comments; furthermore, they feel unsatisfied when they do not receive them. Further, Ferris (2006) revealed that there was a connection between teachers' markings and the students' ability to revise their essays. Such research suggested that teacher WCF was essential in the EFL learning context because feedback could affect students' awareness regarding their writings or compositions.

Wihadi and Martiana (2015) conducted a study in order to assess the effect of teacher WCF on forty senior high school students. The results showed that teacher WCF could decrease students' error rates in a writing task. Furthermore, teacher WCF could encourage the students, and it motivated them in writing since they received adequate experience in composing good quality texts. Students revealed that they had maintained personal contact with their teacher during the course to know more about what the teacher wanted.

\section{Peer Written Corrective Feedback}

According to Kroll (2001), peer review, peer editing, or peer feedback refers to "simply putting students together in groups and then having each student read and react to the strength and weaknesses of each other's papers" (p. 228). Moreover, Hansen and Liu (2005) stated that peer feedback utilizes trained peer reviewers to provide their peers with comments regarding their writings in either written or oral form.

Nowadays, peer WCF is being used in many writing classes. Some researchers have suggested that it can improve students' writing skills (Bijami, Kashef, \& Nejad, 2013; Lee, 2009). Peer WCF usually focuses more on content, organization, and vocabulary, so it leads to less reluctance among students toward accepting a peer's comment, and it is considered to have a faster impact compared to teacher feedback (Gielen, Peeters, Dochy, Onghena, \& Struyven, 2010). Peterson (2013) found that the students who provided feedback achieved a better understanding of the characteristics of good writing by assessing and commenting on their peers' writings. Kusumaningrum, Cahyono, and Prayogo (2019) conducted their research on a sample of 55 EFL university students in Indonesia. The study results revealed that peer feedback provision could increase students' writing achievement levels in both groups.

\section{Self-Written Corrective Feedback}

Self-WCF is defined as the ability to distinguish one's own strengths and weaknesses, and it aims at the development of language components (vocabulary, spelling, tense, and preposition) in one's achievement levels (Lee, 1997; Zimmerman, 2002). Xiang (2004) reported that students should be trained to practice self-monitoring, as it is an effective way to improve students' ability to revise and improve their writing products. Graham and Harris (1996) encouraged students to provide self-feedback for their writing. The 
results revealed that self-feedback could assist students who had low proficiency levels in increasing their writing's quality, length, mechanics, and grammar as well as their perceptions about writing.

Lee (1997) investigated students' competence in terms of correcting surface and meaning errors in a given composition. The students were required to fix the mistakes in three different groups, each receiving the following types of feedback: direct feedback, indirect feedback, and no feedback. The study findings exposed a significant difference, in terms of the students' ability to correct errors, among the three groups. Thus, the study concluded that "when direct cues of error location were provided, their [students'] scores were significantly higher" (p.470).

\section{Comparative Written Corrective Feedback Studies}

Some scholars have compared peer and teacher WCF (Elfiyanto \& Fukazawa, 2020; Yang, Badger, \& Yu, 2006). Yang et al. (2006) stated that students who accepted both teacher and peer feedback could improve their writing ability. Even in this study, the students considered teacher WCF to be more important than peer WCF. However, they also understood the importance of peer WCF and acknowledged that peer WCF could encourage their autonomy. Elfiyanto and Fukazawa (2020) found in their study that Indonesian senior high school students who received peer WCF could enhance their writing abilities compared to students who got teacher WCF. Besides, students who received peer WCF could enhance their abilities in organization and vocabulary. In contrast, students who received teacher WCF could improve their content, organization, vocabulary, and language.

Contradicting the previously mentioned studies, Polio, Fleck, and Leder (1998) analyzed whether or not students revise their texts during revision and whether their effort could reduce sentence-level errors in revised texts after receiving feedback. The result showed that there was a notable improvement in both groups with regards to maintaining grammar accuracy and catching vocabulary errors in the revised texts. However, there were no differences between the achievement levels of the two groups. Therefore, students were able to improve their language without receiving any feedback.

Studies which compared the impact of WCF sources in students' writings yielded a variety of findings. Ganji (2009) examined the impact of providing teacher correction, peer correction, and self-correction on university students' achievement levels in Iran for eight weeks. This study's results revealed that, compared to teacher correction, peer and self-correction were much more efficient during the posttest. It also found that peer correction was useful for providing feedback. Furthermore, Nakanishi (2007) studied the effect of feedback and revision in a group of 40 Japanese female second-year college students. The students were categorized into four different feedback groups: self, peer, teacher, and peer and teacher feedback. The study results showed that the scores of all the groups increased after group members received feedback; furthermore, there was no significant difference between them. The study questionnaire reported that $90 \%$ of students in the peer and teacher feedback group considered the comments they received to be useful for revising their drafts. 
From research studies on this subject, it can be seen that each WCF source has its advantages and disadvantages in enhancing students' writing ability. Secondly, WCF can positively affect senior high school students in EFL countries, such as Indonesia and Japan. Next, by comparing the results of three WCF sources (teacher, peer, and self), we can understand which WCF source is the most useful in Indonesia and Japan in enhancing senior high school students' writing ability. Few studies have been conducted on WCF sources at the senior high school level in EFL countries, like Indonesia and Japan. Thus, this study seeks to advance research in this area by addressing the following questions:

1. How effective was written corrective feedback with regard to improving Indonesian and Japanese senior high school students' achievement levels in essay writing?

2. Among three different sources of written corrective feedback (teacher, peer, and self), which one was the most useful for improving Indonesian and Japanese senior high school students' achievement levels in terms of essay writing?

\section{METHOD}

\section{Participants}

The current study was conducted at two senior high schools in Indonesia and Japan. The participants included 81 senior high school students from Indonesia (31 students in the teacher WCF group, 23 students in the peer WCF group, and 27 students in the selfWCF group). In Japan, the study examined 83 Japanese senior high school students in Grade XI (16-17 years old); however, only 81 students participated in the study from the pretest until the posttest. Three different groups took a general English class, and they included 28 students in the teacher WCF group, 27 students in the peer WCF group, and 26 students in the self-WCF group.

\section{Instruments}

In order to answer the study's research questions, the present researchers gathered two sets of materials for data analysis: students' written essays both during the pretest and the posttest. Besides, the teacher WCF checklist, peer WCF checklist, and self-WCF checklist were used in this study. First, the students' written essays, which were first and second drafts of argumentative essays, were collected from the participants in each country. These two particular kinds of essays were utilized to measure each source of WCF - that is, teacher, peer, and self - that each student experienced on their first draft (pretest); furthermore, it aimed to explore the extent to which each WCF source improved their second drafts (posttest).

In this study, the participant students belonged to the same grade: Grade XI in public senior high schools. Additionally, the current study assumed that these participants would have the same English proficiency level because they had been learning English since junior high school for approximately five years. Furthermore, the pretest results showed that the total mean scores for both groups of participants were considered to be equal. The Indonesian students scored 61.0, and the Japanese senior high school students scored 51.8. Tuyen, Bin Osman, Ahmad, and Dan (2018) adopted Tribble's 
scoring rubric and converted the scoring metrics into four levels: Excellent to Good, Fair, Average, and Poor. In their study, the Excellent to Good standard had a score range of 100-80. The Fair level is a score between 79-65. If the students have a score from 64 to 50, they will be in the Average level. For students who get a score under 49, they belong to the Poor standard. Based on these criteria, the pretest results were determined to belong to the Average level.

Furthermore, Tribble's (1996) scoring rubric was chosen because it provided detailed information about the criteria for each writing element. Thus, in this study, the total score for each writing assignment was 100 . The detailed information can be seen in Table 1 below.

Table 1

The criteria of writing assessment

\begin{tabular}{lllllll}
\hline \multirow{2}{*}{ Area } & Measure & \multicolumn{2}{l}{ Level } & & & \\
\cline { 2 - 6 } Content & $\begin{array}{l}\text { Excellent- } \\
\text { Very Good }\end{array}$ & $\begin{array}{l}\text { Good- } \\
\text { Average } \\
\text { argument, detailed }\end{array}$ & $\begin{array}{l}\text { Fair- } \\
\text { Poor }\end{array}$ & $\begin{array}{l}\text { Very } \\
\text { Poor }\end{array}$ & Inadequate \\
\hline Organization & $\begin{array}{l}\text { expression, ideas, } \\
\text { paragraphing, } \\
\text { coherence, cohesion }\end{array}$ & $20-17$ & $16-12$ & $11-8$ & $7-5$ & $4-0$ \\
\hline Vocabulary & $\begin{array}{l}\text { words/idioms and } \\
\text { usage }\end{array}$ & $20-17$ & $16-12$ & $11-8$ & $7-5$ & $4-0$ \\
\hline Language & $\begin{array}{l}\text { grammar, word order, } \\
\text { art., pron., prep. } \\
\text { meaning }\end{array}$ & $30-24$ & $23-18$ & $17-10$ & $7-5$ & $4-0$ \\
\hline Mechanics & $\begin{array}{l}\text { spelling, punc., } \\
\text { capitalization }\end{array}$ & $10-8$ & $7-5$ & $4-2$ & $5-0$ \\
\hline
\end{tabular}

\section{The Study Design}

This experimental research investigated three different groups of students who received feedback from three different types of sources. Each group was randomly selected to receive feedback from different kinds of sources for their writing tasks. Group A received Teacher WCF, Group B received Peer WCF, and Group C received Self-WCF.

The study was conducted during four meetings held over three weeks. The pretest was held in the first meeting. During this meeting, the three groups had to write an in-class composition for their first draft assignment; this was considered as the pretest. The pretest itself used the following topic: "Should senior high school students join club activities?" The students had to compose an argumentative essay on this topic within 40 minutes. During the second and third meetings, classroom English teachers conducted the treatment, including training their students in composing good essays and receiving and providing feedback by explaining the usage of the feedback checklist. The checklist contained assessments regarding their writing on organization, content, word choice, fluency, conventions, and reflections. This treatment was completed within 50 minutes in every meeting. 
During the fourth meeting, the participants were required to review their own first draft (pretest). For example, teacher WCF group participants revised their first draft based on the WCF they received from their teacher. Here, the teachers used the teacher WCF checklist to provide corrective feedback on the students' compositions. Next, in the peer WCF group, the teacher distributed the pretest randomly, and it included an attached peer feedback checklist. This feedback process took about 15 minutes, and then the peers returned their friends' writing with their feedback attached. Next, the students in the self-WCF group received their own first draft. They checked their first composition by consulting the self-WCF checklist provided by the teacher. This process took around 10-15 minutes. After reading the feedback provided by each WCF source, the students were required to revise their first draft/pretest; at this point, the study moved to the posttest step. This revision took about 30-35 minutes, and the whole process took about 45-50 minutes. The same topic was used for the pretest and the posttest. The data collection process was completed in three weeks. Figure 1 provides detailed information about this process.

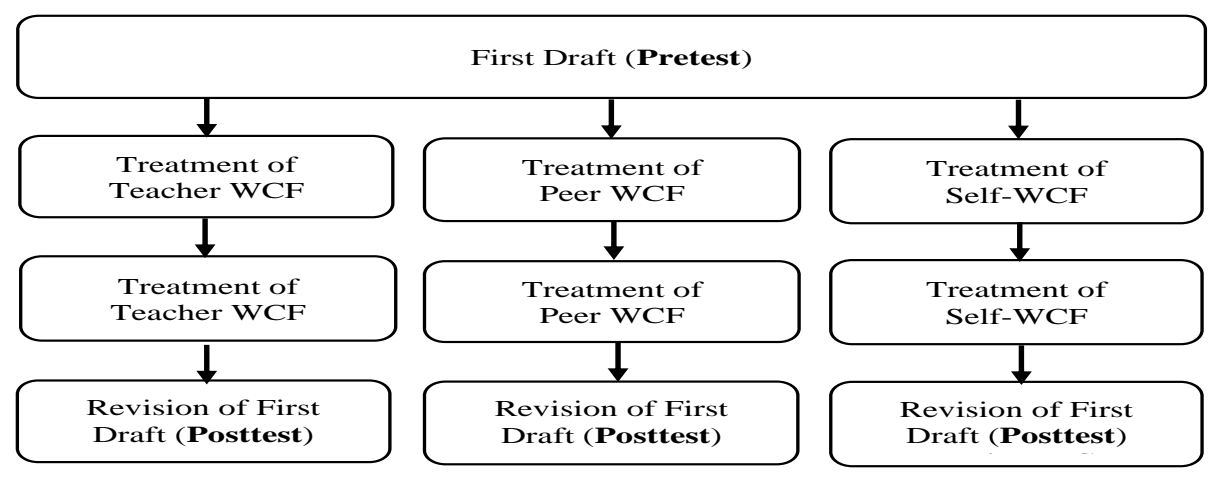

Figure 1

Sequence of the writing process in the study

\section{Data Analysis}

The achievement levels utilized during this study were based on the pretest and the posttest. Tribble's scoring rubric was applied to assess students' written essays. Moreover, the senior high schools where the study was conducted also utilized this rubric.

Two experienced Indonesian English teachers who had been teaching for more than 20 years rated all the writing products in the pretest and the posttest. They assessed works produced by both the Indonesian and the Japanese participants. To verify their rating reliability, we utilized a tryout with 34 students of grade XI who had a different group from the participants but in the same school in Indonesia. They produced written assignments on the same topic (entitled "Should senior high school students join club activities?") along with the participants. The score was then measured using SPSS 23 to measure the reliability before the raters assessed the participants' compositions. The result of the interrater analysis was 0.81 , with $p<0.001$. According to Landis and Koch 
(1977), the score of the Kappa result can be interpreted as follows: values $\leq 0$ indicates poor, and $0.01-0.20$ indicates none to slight, $0.21-0.40$ as fair, $0.41-0.60$ as moderate, $0.61-0.80$ as substantial, and $0.81-1.00$ as an almost perfect agreement. Therefore, the reliability score results showed a high level of agreement between the two raters in terms of scoring writing products.

In order to measure the relationship between students' achievement levels in terms of writing and the WCF sources they received; the data were analyzed using a one-way Analysis of Variance (ANOVA). Furthermore, a post hoc Bonferroni test was performed to provide specific information regarding which WCF sources were most effective for improving writing achievement.

\section{FINDINGS}

Table 2 shows the detailed scores for the pretest and posttest in both countries. Based on the pretest results, the Indonesian (IDN) senior high school students had the least score for the Teacher WCF group at 42, and the highest score was 89. The peer WCF group got the lowest score of 45 and the highest score of 81 . Students in the self-WCF group obtained 42 as the lowest score and 78 as the highest score. The teacher WCF group obtained 58 as the lowest score and 91 as the highest score in the posttest. For the peer WCF group, the minimum score was 57 , and the maximum score was 90 . Last, for the self-WCF group, the lowest score was 43, and the highest score was 85 .

In Japan (JPN), the pretest scores showed that, for the teacher WCF group, the highest score was 73, and the lowest score was 38. In the peer WCF group, the students received 82 as the maximum score and 41 as the minimum score. The self-WCF group received the highest score of 64 and the lowest score of 33. The teacher WCF group scored 90 as the highest score and 50 as the lowest score regarding the posttest scores. The peer WCF group received 81 as the maximum score and 50 as the minimum score. Finally, the highest score for the self-WCF group was 66, and the lowest score was 36. Thus, the descriptive statistics revealed that the scores of WCF sources for Indonesian and Japanese senior high school students improved between the pretest and the posttest.

Table 2

Descriptive statistics for Indonesia and Japan

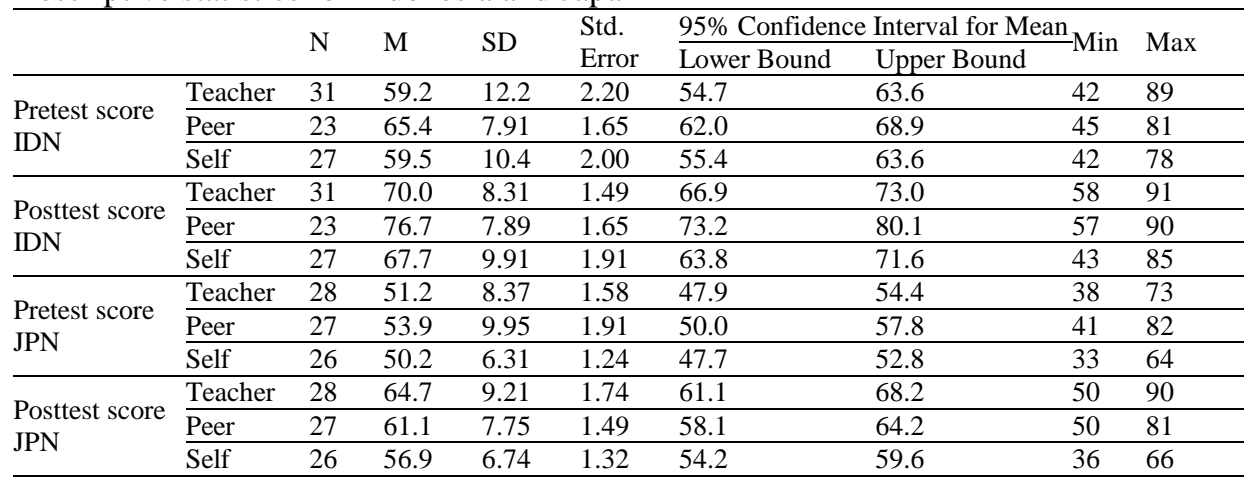


Table 2 presents the mean scores in terms of the pretest and posttest of the two countries. The results show that three kinds of feedback sources could enhance students' achievement levels in essay writing. This was indicated by the increasing scores and mean scores between the posttest from the pretest. For example, the Indonesian students in the teacher WCF group had a mean score of 59.2 in the pretest. But for the posttest, their mean score had progressed to 70.0. Their minimum and maximum scores in the posttest also were higher than what they achieved in the pretest.

Similar results were also obtained with Japanese senior high school students. Their mean scores increased from 51.2 to 64.7 in the teacher WCF group. Besides, their minimum score in the pretest was 38 , but in the posttest, it increased to 50. Moreover, their maximum score improved from 73 to 90 .

Like the teacher WCF group, the peer WCF and self WCF groups also improved their writing achievement. Consequently, Research Question 1-whether WCF is effective in improving senior high school students' achievement levels in essay writing in EFL countries such as Indonesia and Japan - was answered in the affirmative.

However, to answer Research Question 2-what sort of WCF sources are the most effective in an EFL senior high school - it is necessary to conduct an ANOVA and post hoc test. One of the assumptions for conducting ANOVA is that the variances are equal. In Table 3, the Test of Homogeneity of Variances shows that three different groups in both countries were equal. The $p$-values in the pretest were as follows: 0.11 for the Indonesian students and 0.17 for the Japanese students. In the posttest, the results were as follows: 0.65 for the Indonesian students and 0.69 for the Japanese students. Thus, these $p$-values indicated the validity of the ANOVA application.

Table 3

Test of homogeneity of variances

\begin{tabular}{lllll}
\hline & Levene Statistic & df1 & df2 & Sig. \\
\hline Pretest score IDN & 2.26 & 2 & 78 & 0.11 \\
\hline Pretest score JPN & 1.84 & 2 & 78 & 0.17 \\
\hline Posttest score IDN & 0.44 & 2 & 78 & 0.65 \\
\hline Posttest score JPN & 0.38 & 2 & 78 & 0.69 \\
\hline
\end{tabular}

The next step was conducted to identify whether there were different scores between the three different feedback sources; the ANOVA test was applied. 
Table 4

ANOVA table for both countries

\begin{tabular}{|c|c|c|c|c|c|c|}
\hline & & SS & df & MS & $\mathrm{F}$ & Sig. \\
\hline \multirow{3}{*}{$\begin{array}{l}\text { Pretest score } \\
\text { IDN }\end{array}$} & Between Groups & 619.22 & 2 & 309.61 & 2.783 & 0.068 \\
\hline & Within Groups & 8676.59 & 78 & 111.24 & & \\
\hline & Total & 9295.80 & 80 & & & \\
\hline \multirow{3}{*}{$\begin{array}{l}\text { Pretest score } \\
\text { JPN }\end{array}$} & Between Groups & 192.61 & 2 & 96.31 & 1.376 & 0.259 \\
\hline & Within Groups & 5457.39 & 78 & 69.97 & & \\
\hline & Total & 5650.00 & 80 & & & \\
\hline \multirow{3}{*}{$\begin{array}{l}\text { Posttest } \\
\text { score IDN }\end{array}$} & Between Groups & 1060.19 & 2 & 530.09 & 6.898 & 0.002 \\
\hline & Within Groups & 5993.82 & 78 & 76.84 & & \\
\hline & Total & 7054.00 & 80 & & & \\
\hline \multirow{3}{*}{$\begin{array}{l}\text { Posttest } \\
\text { score JPN }\end{array}$} & Between Groups & 811.63 & 2 & 405.81 & 6.344 & 0.003 \\
\hline & Within Groups & 4989.36 & 78 & 63.97 & & \\
\hline & Total & 5800.99 & 80 & & & \\
\hline
\end{tabular}

Table 4 describes a difference in the mean scores for both countries in the posttest result. In other words, students' abilities in the three groups before being tested had the same average score. Furthermore, after receiving treatment, these three groups showed differences in average both in Indonesia and Japan. Table 4 also illustrates that the values of $\mathrm{F}$ in the posttest are 6.898 for Indonesian students and 6.344 for the Japanese students. Besides, the results showed that the $p$-values of the Indonesian students were 0.002, while for the Japanese students the figure was 0.003 , which is less than the 0.05 alpha level. Thus, the three groups in both countries had statistically different average scores in the posttest. As a result of the ANOVA not providing detailed information regarding the differences among three WCF sources, additional analysis is needed to clarify the differences.

Moreover, it is essential to conduct a post hoc test to identify the most useful feedback sources from teacher, peer, and self-WCF. The homogeneity test in Table 4 showed that the three types of feedback sources had an equal impact; therefore, the Bonferroni post hoc test was employed. McDonald (2014) said that the Bonferroni post hoc test is suitable when a single false positive in a test set would be a problem. It is mainly beneficial when there are a relatively small number of multiple comparisons and there is a need to find one or two that might be significant. 
Table 5

Multiple Comparisons between Indonesia and Japan

\begin{tabular}{|c|c|c|c|c|c|c|c|}
\hline \multicolumn{8}{|l|}{ Bonferroni } \\
\hline \multirow{2}{*}{$\begin{array}{l}\text { Dependent } \\
\text { Variable }\end{array}$} & \multirow{2}{*}{$\begin{array}{l}\text { (I) } \\
\text { Condition }\end{array}$} & \multirow{2}{*}{$\begin{array}{l}(\mathrm{J}) \\
\text { Condition }\end{array}$} & \multirow{2}{*}{$\begin{array}{l}\text { Mean Difference } \\
(\mathrm{I}-\mathrm{J})\end{array}$} & \multirow{2}{*}{$\begin{array}{l}\text { Std. } \\
\text { Error }\end{array}$} & \multirow{2}{*}{ Sig. } & \multicolumn{2}{|c|}{$95 \%$ Confidence Interval } \\
\hline & & & & & & Lower Bound & Upper Bound \\
\hline \multirow{6}{*}{$\begin{array}{l}\text { Pretest } \\
\text { score IDN }\end{array}$} & \multirow{2}{*}{ Teacher } & Peer & -6.27 & 2.90 & 0.101 & -13.38 & 0.83 \\
\hline & & Self & -0.32 & 2.78 & 1.000 & -7.11 & 6.47 \\
\hline & \multirow{2}{*}{ Peer } & Teacher & 6.27 & 2.90 & 0.101 & -0.83 & 13.38 \\
\hline & & Self & 5.95 & 2.99 & 0.151 & -1.37 & 13.28 \\
\hline & \multirow{2}{*}{ Self } & Teacher & 0.32 & 2.78 & 1.000 & -6.47 & 7.11 \\
\hline & & Peer & -5.95 & 2.99 & 0.151 & -13.28 & 1.37 \\
\hline \multirow{6}{*}{$\begin{array}{l}\text { Posttest } \\
\text { score IDN }\end{array}$} & \multirow{2}{*}{ Teacher } & Peer & $-6.68 *$ & 2.41 & 0.021 & -12.59 & -0.78 \\
\hline & & Self & 2.26 & 2.31 & 0.989 & -3.38 & 7.91 \\
\hline & \multirow{2}{*}{ Peer } & Teacher & $6.68 *$ & 2.41 & 0.021 & 0.78 & 12.59 \\
\hline & & Self & $8.95 *$ & 2.49 & 0.002 & 2.86 & 15.03 \\
\hline & \multirow{2}{*}{ Self } & Teacher & -2.26 & 2.31 & 0.989 & -7.91 & 3.38 \\
\hline & & Peer & $-8.95^{*}$ & 2.49 & 0.002 & -15.03 & -2.86 \\
\hline \multirow{6}{*}{$\begin{array}{l}\text { Pretest } \\
\text { score JPN }\end{array}$} & \multirow{2}{*}{ Teacher } & Peer & -2.71 & 2.26 & 0.700 & -8.23 & 2.81 \\
\hline & & Self & 0.95 & 2.28 & 1.000 & -4.63 & 6.52 \\
\hline & \multirow{2}{*}{ Peer } & Teacher & 2.71 & 2.26 & 0.700 & -2.81 & 8.23 \\
\hline & & Self & 3.66 & 2.30 & 0.347 & -1.97 & 9.28 \\
\hline & \multirow{2}{*}{ Self } & Teacher & -0.95 & 2.28 & 1.000 & -6.52 & 4.63 \\
\hline & & Peer & -3.66 & 2.30 & 0.347 & -9.28 & 1.97 \\
\hline \multirow{6}{*}{$\begin{array}{l}\text { Posttest } \\
\text { score JPN }\end{array}$} & \multirow{2}{*}{ Teacher } & Peer & 3.53 & 2.16 & 0.317 & -1.75 & 8.81 \\
\hline & & Self & $7.76^{*}$ & 2.18 & 0.002 & 2.43 & 13.09 \\
\hline & \multirow{2}{*}{ Peer } & Teacher & -3.53 & 2.16 & 0.317 & -8.81 & 1.75 \\
\hline & & Self & 4.23 & 2.20 & 0.175 & -1.15 & 9.60 \\
\hline & \multirow{2}{*}{ Self } & Teacher & $-7.76^{*}$ & 2.18 & 0.002 & -13.09 & -2.43 \\
\hline & & Peer & -4.23 & 2.20 & 0.175 & -9.60 & 1.15 \\
\hline
\end{tabular}

*. The mean difference is significant at the 0.05 level.

Table 5 displays the statistically significant mean differences, which are flagged with an asterisk $\left(^{*}\right)$. For instance, in the posttest score for Indonesian students, the very first line shows that Teacher (I) to Peer (J) has a mean difference of -6.68 points lower than Peer (I) to Teacher (J), which has 6.68. "Sig." $<0.05$ indicates a statistically significant difference between three mean scores (see the Sig. column). The posttest scores of Indonesian students received a significant value of 0.021 for Peer and Teacher and 0.002 for Peer and Self-WCF. Last, a 95\% confidence interval column, not including zero, means that a zero difference between these means in the population is unlikely. Thus, based on the Bonferroni post hoc test, it can be said that the Indonesian senior high school students could enhance their writing abilities through peer WCF.

On the other hand, the posttest score for the Japanese senior high school students shows that Teacher (I) to Self (J) has a mean difference of 7.76 points higher than Self (I) to Teacher (J), which has -7.76 . Next, "Sig." < 0.05 indicates a statistically significant difference between Teacher and Self-WCF mean scores (see the Sig. column). The Japanese senior high school students in the posttest score received a significant value of 0.002 for Teacher and Self and also for Self and Teacher WCF. Last, a 95\% confidence interval column, not including zero, means that a zero difference between these means in 
the population is unlikely. As a result, the Japanese students' posttest score indicates that teacher WCF is effective feedback to improve their writing abilities.

\section{DISCUSSION}

This study intended to examine the effectiveness of WCF in increasing Indonesian and Japanese senior high school students' achievement levels in English writing. It compared the pretest and posttest results for each group to identify the significant effects for EFL countries such as Indonesia and Japan. A series of one-way ANOVA indicated the posttest of the WCF sources groups in Indonesia and Japan showed significant improvement. All three different WCF sources displayed a more positive role in improving students' writing ability. This finding was similar to Nakanishi (2007), who compared self-WCF with peer and teacher WCF on the writing of Japanese EFL students. The findings of that study revealed that the writing quality scores improved compared to those of previous tests. Furthermore, teacher and peer WCF were perceived as the most useful, and concrete feedback was the most useful for revising first drafts.

This study also indicated that the Indonesian and Japanese senior high school students had different ways of improving their English writing performance. Among the Indonesian students, peer WCF was considered an effective way of increasing their writing performance regarding English essay writing. These results agree with Mendonça and Johnson's (1994) study, which found that peer feedback was an effective way of enhancing writing accuracy and achievement levels.

On the other hand, among the Japanese senior high school students, teacher WCF had a more significant impact than peer and self-WCF. This tendency was reflected in the improvement between the pretest and posttest scores in this study. The students perceived their teacher as a person who had expertise and, thus, their primary feedback source. Deng (2016) shows Japanese students were found to rely heavily on teachers for error detection and correction. Similarly, most teachers also consider that providing feedback is their job, to detect and correct students' error. MEXT (2019) states that the enhancement of school education largely depends on teachers' quality and abilities, who directly play the central role. Thus, Japanese education utilizes a teacher-centered system where the teacher delivers knowledge to the students. Therefore, teacher WCF is dominant and has a significant impact on improving students' abilities. Baierschimidht (2012) supported this idea by saying that even though the participants showed positive affective regard for peer WCF, they still preferred teacher WCF over peer WCF. She also stated that none of her study participants showed great self-confidence while reviewing their peer's compositions.

O'Flaherty (2016) also stated that Japanese senior high school students had more confidence in teacher WCF. They thought their teachers were more experienced and produced better quality WCF. Besides, the students viewed error correction as the teacher's responsibility.

Sadoshima and Ohta (2013) found that peer feedback could develop students' confidence and motivation for learning writing. Further, encouraging peer WCF provides other benefits such as developing critical thinking and inducing students to become more active in teaching and learning activities. Still, there remains a possibility 
that students may be hesitant to indicate their peers' errors even when they are aware of them; even though peer WCF has certain benefits, it can only be offered if learners find it suitable. This finding agrees with that of Yang et al. (2006), who revealed that teacher WCF had a more significant impact and produced more student improvements than peer WCF.

The posttest scores suggest that senior high school students from both Indonesia and Japan still perceive that self-WCF is not significant enough to be implemented in class. This finding may have been influenced by the students' lack of confidence in their checking and feedback for their own essays. Ferris and Hedgcock (2005) stated that, while teacher and peer WCF were effective, it was still necessary for teachers to train their students to foster self-WCF, as one major goal of teaching writing is to encourage students to become independent and autonomous self-editors. Besides, Nakanishi (2007) found that training students to provide self-WCF could significantly impact metaknowledge and overall writing quality. Further, such students showed significant grammar improvements, and they even indicated that this improvement was caused by self-feedback training. This source of feedback can be applied as a first step in checking students' essays because it was found that the final scores increased in the self-WCF groups.

\section{CONCLUSION}

This study's results indicate that WCF, regardless of the feedback sources, plays a vital role in developing senior high school students' English writing abilities in Indonesia and Japan. The study indicated that peer WCF was effective for improving Indonesian senior high school students' achievement levels in English writing. Study results also showed that teacher and self-WCF could increase students' performance in terms of English writing. However, their effect was not as significant as that of peer WCF in the Indonesian context. On the other hand, Japanese senior high school students who experienced teacher WCF showed considerable improvement compared to those who experienced peer and self-WCF.

Furthermore, this study's findings can be applied pedagogically when EFL teachers-in this case, Indonesian and Japanese English teachers-need to choose WCF sources for their students. The findings have the potential to significantly improve senior high school students' achievement levels in English writing in Indonesia and Japan. It can be recommended that both Indonesian and Japanese teachers should combine three different WCF sources in their classes to boost their students' writing ability to optimal levels. Igarashi (2019) states that students must build their self-revision strategies and skills to reduce grammar mistakes gradually. Practicing teacher and peer WCF could help them become independent writers who, later on, could perform self-WCF and thus become autonomous writers. However, further studies are necessary for investigating which writing criteria (from among those provided in Tribble's scoring rubrics) can be developed most by certain types of feedback sources.

Moreover, this study suggests that teachers should train their students about feedback checklist usage, which can help them effectively edit their compositions. Providing students with the time and opportunity to read and revise their own and other students' 
writing drafts could help them become better writers. This assertion agrees with Diab's (2016) findings, who suggested that writing teachers should train students in providing WCF (self and peer). Furthermore, teachers should check students' WCF and comment on their writing so that they can build their own trust-as well as peer WCF; this, in turn, could reduce the amount of teacher feedback. Further, it will increase students' confidence in their English writing ability, since their teachers will also be reading and paying attention to their products.

This study has three limitations. First, because of the schools' policy, the time utilized for conducting the research - only four meetings - was inadequate, where each lasted for 45-50 minutes. Thus, the students received limited experience with the teacher, peer, and self-WCF, and this, in turn, reduced the generalizability of the quality and quantity of the feedback they provided and received. Second, every country has its own goals and techniques for teaching English writing within their curriculums. These differences often influence the experience and background knowledge of the students. Last, we did not interview the students to understand the reasons underlying their respective achievement levels or preferences for utilizing WCF sources.

\section{ACKNOWLEDGMENT}

The first author would like to thank the LPDP (Lembaga Pengelola Dana Pendidikan) Minister of Finance, the Republic of Indonesia, for the generous support provided to this study.

\section{REFERENCES}

Ariyanti, A., \& Fitriana, R. (2017). EFL students' difficulties and needs in essay writing. In International Conference on Teacher Training and Education 2017 (ICTTE 2017). Atlantis Press. https://dx.doi.org/10.2991/ictte-17.2017.4

Baierschimidt, J. (2012). Japanese ESL learner attitudes towards peer feedback. The Journal of Kanda University of International Studies, 24, 101-114.

Bijami, M., Kashef, S. H., \& Nejad, M. S. (2013). Peer feedback in learning English writing: Advantages and disadvantages. Journal of Studies in Education, 3(4), 91-97. https://doi:10.5296/jse.v3i4.4314

Bitchener, J., \& Ferris, D. (2012). Written corrective feedback in second language acquisition and writing. New York: Routledge.

Bitchener, J., \& Storch, N. (2016). Written corrective feedback for L2 development. Bristol: Multilingual Matters.

Chandler, J. (2003). The efficacy of various kinds of error feedback for improvement in the accuracy and fluency of L2 student writing. Journal of Second Language Writing, 12(3), 267-296. https://doi.org/10.1016/S1060-3743(03)00038-9

Chen, S., Nassaji, H., \& Liu, Q. (2016). EFL learners' perceptions and preferences of written corrective feedback: a case study of university students from Mainland China. Asian-Pacific Journal of Second and Foreign Language Education, 1(1), 5. https://doi.org/10.1186/s40862-016-0010-y 
Deng, K. (2016). Written corrective feedback: Issues and implications. Journal of Modern Education Review, 6(11), 824-829.

Diab, N. M. (2016). A comparison of peer, teacher and self-feedback on the reduction of language errors in student essays. System, 57, 55-65. https://doi.org/10.1016/j.system.2015.12.014

Elfiyanto, S., \& Fukazawa, S. (2020). Effect of teacher and peer written corrective feedback on writing components in EFL classrooms. JEES (Journal of English Educators Society), 5(2), 185-191. https://doi.org/10.21070/jees.v5i2.826

Ferris, D. R. (1999). The case for grammar correction in L2 writing classes: A response to Truscott (1996). Journal of Second Language Writing, 8(1), 1-11. https://doi.org/10.1016/S1060-3743(99)80110-6

Ferris, D. R. (2006). Does error feedback help student writers? New evidence on the short- and long-term effects of written error correction. In K. Hyland, \& F. Hyland (Eds.), Feedback in second language writing: Contexts and issues (pp. 81-104). Cambridge: Cambridge University Press. https://doi.org/10.1017/CBO9781139524742.007

Ferris, D. R., \& Hedgcock, J. S. (2005). Teaching ESL composition. Purpose, process, and practice (2nd ed.). Mahwah, New Jersey: Lawrence Erlbaum Associates.

Ganji, M. (2009). Teacher-correction, peer-correction and self-correction: Their impacts on Iranian students' IELTS essay writing performance. The Journal of Asia TEFL, 6(1), $117-139$.

Gielen, S., Peeters, E., Dochy, F., Onghena, P., \& Struyven, K. (2010). Improving the effectiveness of peer feedback for learning. Learning and Instruction, 20(4), 304-315. https://doi.org/10.1016/j.learninstruc.2009.08.007

Graham, S., \& Harris, K. R. (1996). Self-regulation and strategy instruction for students who find writing and learning challenging. In C. M. Levy \& S. Ransdell (Eds.), The science of writing: Theories, methods, individual differences, and applications (pp. 347360). Lawrence Erlbaum Associates, Inc.

Hansen, J. G., \& Liu, J. (2005). Guiding principles for effective peer response. ELT Journal, 59(1), 31-38. https://doi.org/10.1093/elt/cci004

Hattie, J. \& Timperley, H. (2007). The power of feedback. Review of Educational Research, 77(1), 81-112. https://doi.org/10.3102/003465430298487

Hendrickson, J. M. (1978). Error correction in foreign language teaching: Recent theory, research, and practice. Modern Language Journal, 62, 387-398. https://doi.org/10.1111/j.1540-4781.1978.tb02409.x

Igarashi, S. (2019). Facilitating revision skill in L2 writing instruction: The roles of teacher and peer feedback. Accents Asia,11(2), 13-32. 
Kemendikbud (Kementerian Pendidikan dan Kebudayaan). (2013). Permendikbud Nomor 69 tahun 2013 tentang KD dan Struktur Kurikulum SMA-MA [The decree of the Ministry of Education number 692013 about senior high school's basic competence and curriculum structure]. Retrieved October 15, 2020, from http://bsnpindonesia.org/2013/06/20 /permendikbud-tentang-kurikulum-tahun-2013/

Kroll, B. (2001). Considerations for teaching an ESL/EFL writing course. In M. CelceMurcia (Ed.). Teaching English as a Second or Foreign Language (3rd ed.) (pp.219232). Boston, MA: Heinle and Heinle.

Kusumaningrum, S. R., Cahyono, B. Y., \& Prayogo, J. A. (2019). The effect of different types of peer feedback provision on EFL students' writing performance. International Journal of Instruction, 12(1), 213-224. https:// doi.org/10.29333/iji.2019.12114a

Landis, J. R. \& Koch, G. G. (1977). The measurement of observer agreement for categorical data. Biometrics, 33(1), 159-174. https://doi.org/10.2307/2529310

Lee, I. (1997). ESL learners' performance in error correction in writing: some implications for teaching. System, 25(4), 465-477. https://doi.org/10.1016/S0346251X(97)00045-6

Lee, I. (2009). Feedback revolution: What gets in the way?. ELT Journal, 65(1), 1-12. https://doi.org/10.1093/elt/ccp028

McDonald, J. H. (2014). Handbook of biological statistics (3rd ed.). Baltimore, Maryland: Sparky House Publishing.

Mendonca, C. O., \& Johnson, K. E. (1994). Peer review negotiations: Revision activities in ESL writing instruction. TESOL Quarterly, 28(4), 745-770.

https://doi.org/10.2307/3587558

Minister of Education, Culture, Sports, Science, and Technology (MEXT). (2011). Section 9 Foreign languages. Retrieved October 15, 2020, from http://www.mext.go.jp/ component/english/_icsFiles/afieldfile/2011/03/17/1303755_013.pdf.

Minister of Education, Culture, Sports, Science, and Technology (MEXT). (2019). Overview of the Ministry of Education, Culture, Sports, Science and Technology. Retrieved October 15, 2020, from https://www.mext.go.jp/en/about/pablication /_icsFiles/afieldfile/2019/03/13/1374478_001.pdf

Nakanishi, C. (2007). The effects of different types of feedback on revision. The Journal of Asia TEFL, 4(4), 213-244.

O'Flaherty, D. (2016). Japanese high school students' attitudes towards and usage of corrective feedback on their written work. The Language Teacher, 40(6), 3-8. https://doi.org/10.37546/JALTTLT40.6-1

Okada, R. (2018). Challenges in teaching Japanese EFL students to express themselves logically. Asian Education Studies, 3(1), 73-82. https://doi.org/10.20849/aes.v3i1.335

Peterson, S. S. (2013). Peer feedback on writing: An assessment for learning tool. Research for Teachers, 13, 1-3. 
Polio, C., Fleck, C., \& Leder, N. (1998). "If I only had more time": ESL learners' changes in linguistic accuracy on essay revisions. Journal of Second Language Writing, 7(1), 43-68. https://doi.org/10.1016/S1060-3743(98)90005-4

Richards, J. C., \& Renandya, W. A. (Eds.). (2002). Methodology in language teaching: An anthology of current practice. Cambridge: Cambridge University Press.

Sadoshima, S., \& Ohta, Y (Eds). (2013). Bunsho tutoring no riron to jissen [Theory and practice for writing tutoring]. Tokyo: Hitsuji Shobo.

Tillema, M. (2012). Writing in first and second language. Empirical studies on text quality and writing processes. Utrecht: University of Utrecht (Doctoral Dissertation). Retrieved October 17, 2020, from http://dspace.library.uu.nl/handle/1874/241028.

Toba, R. G., Noor, W. N., \& Sanu, L.O. (2019). The current issues of Indonesian EFL students' writing skills: Ability, problem, and reason in writing comparison and contrast essay. Dinamika Ilmu, 19, 57-73. https://doi.org/10.21093/DI.V19I1.1506

Tribble, C. (1996). Writing. Oxford: Oxford University Press.

Truscott, J. (1996). The case against grammar correction in L2 writing classes. Language Learning, 46(2), 327-369. https://doi.org/10.1111/j.14671770.1996.tb01238.x

Truscott, J., \& Hsu, A. Y. P. (2008). Error correction, revision, and learning. Journal of second language writing, 17(4), 292-305. https://doi.org/10.1016/j.jslw.2008.05.003

Tuyen, K. T., Bin Osman, S., Ahmad, N. S. B., \& Dan, T. C. (2018). Developing and validating scoring rubrics for the assessment of research papers writing ability of EFL/ESL undergraduate students: The effects of research papers writing intervention program using process genre model of research paper writing. International Journal of Language, Literature, Culture and Education, 1, 1-17.

Van Beuningen, C. G., De Jong, N. H., \& Kuiken, N. F. (2012). Evidence on the effectiveness of comprehensive error correction in second language writing. Language Learning, 62(1), 1-41. https://doi.org/10.1111/j.1467-9922.2011.00674.x

Wihadi, M., \& Martiana, I. (2015). The effect of teacher's written feedbacks on Indonesian EFL learners' recount writing competence. Indonesian EFL Journal, l(1), 58-62. https://doi.org/10.25134/ieflj.vli1.614

Xiang, W. (2004). Encouraging self-monitoring in writing by Chinese students. ELT Journal, 58(3), 238-246. https://doi.org/10.1093/elt/58.3.238

Yang, M., Badger, R., \& Yu, Z. (2006). A comparative study of peer and teacher feedback in a Chinese EFL writing class. Journal of Second Language Writing, 15(3), 179-200. https://doi.org/10.1016/j.jslw.2006.09.004

Yoshida, K. (2008). TEFL in Japan: An overview. Proceeding of the $15^{\text {th }}$ World Congress of AILA, 1-8. Essen: University Duisburg-Essen, 25 Aug, 2008.

Zimmerman, B. J. (2002). Becoming a self-regulated learner: An overview. Theory into Practice, 4l(2), 64-70. https://doi.org/10.1207/s15430421tip4102_2 